\title{
Surface Coating of Pancreatic Islets With Neural Crest Stem Cells Improves Engraftment and Function After Intraportal Transplantation
}

\author{
Joey Lau,* Svitlana Vasylovska, ${ }^{*} \dagger$ Elena N. Kozlova, $†$ and Per-Ola Carlsson* $*$ \\ *Department of Medical Cell Biology, Uppsala University, Uppsala, Sweden \\ $†$ Department of Neurosciences, Uppsala University, Uppsala, Sweden \\ \$Department of Medical Sciences, Uppsala University, Uppsala, Sweden
}

\begin{abstract}
The present study aimed to develop techniques for surface coating of islets with neural crest stem cells (NCSCs) in order to enable cotransplantation to the clinically used liver site and then investigate engraftment and function intraportally of such bioengineered islets. Mouse islets were coated during incubation with enhanced green fluorescent protein (EGFP)-expressing mouse NCSCs and transplanted into the portal vein to cure diabetic mice. An intravenous glucose tolerance test was performed at 1 month posttransplantation. Islet grafts were retrieved and evaluated for vascular density, nerves, and glial cells. NCSCs expressed a vast number of key angiogenic and neurotrophic factors. Mice transplanted with NCSC-bioengineered islets responded better to the glucose load than recipient mice with control islets. NCSCs remained present in the vicinity or had often migrated into the NCSC-coated islets, and an improved islet graft reinnervation and revascularization was observed. Transplanted NCSCs differentiated into both glial and neural cells in the islet grafts. We conclude that bioengineering of islets with NCSCs for intraportal transplantation provides a possibility to improve islet engraftment and function. Pending successful establishment of protocols for expansion of NCSCs from, for example, human skin or bone marrow, this strategy may be applied to clinical islet transplantation.
\end{abstract}

Key words: Islet transplantation; Stem cells; Neural progenitors; Engraftment; Revascularization; Reinnervation

\section{INTRODUCTION}

Islet transplantation intraportally into the liver is an established treatment option for $\beta$-cell replacement in type 1 diabetic patients with poor glycemic control and frequent episodes of hypoglycemia. However, in most cases, two donor pancreases are needed to reverse hyperglycemia, which is far more than the alleged $10-30 \%$ of the total islet volume suggested to be enough to maintain normoglycemia in humans. Moreover, there seems to be a progressive decline in function of islet transplants (34). Several factors may contribute to islet graft dysfunction at the liver site, which includes early cell death, lipotoxicity, immunological factors, as well as insufficient engraftment $(10,14,23,25)$. Noteworthy, especially islets that are undamaged and that remain intact following intraportal transplantation are poorly vascularized (14), and prevailing hypoxia with correlating increased apoptosis rates can be observed up to 3 months posttransplantation (30). Similarly, $20 \%$ of intraportally transplanted islets are still totally devoid of innervation at this time point (20).
Strategies with cotransplantation of islets with different supporting cells or decorated scaffolds have been tested at extrahepatic sites to improve and accelerate engraftment $(12,16)$. However, such strategies need to be modified in order to permit application at the intraportal site. Coating of islet surfaces has been successfully performed with heparin in order to diminish instant blood-mediated inflammatory reactions following intraportal transplantation (5), whereas such protocols have only been tested in vitro for cell therapies (18).

We have recently shown the importance of reorganization of islet matrix by matrix metalloproteinases in order to allow engraftment of intraportally transplanted islets (14). Interestingly, besides producing a number of growth factors, neural crest-derived stem cells (NCSCs) naturally express these enzymes to allow their migration (26) and have also been shown to markedly promote angiogenesis and neural remodeling in infarcted heart (6). The present study tested the hypothesis that NCSCs could be coated to islet surfaces prior to transplantation and could provide

Received January 21, 2014; final acceptance December 19, 2014. Online prepub date: January 9, 2015.

Address correspondence to Per-Ola Carlsson, M.D., Ph.D., Department of Medical Cell Biology, Uppsala University, Husargatan 3, box 571, SE-75123 Uppsala, Sweden. Tel: +46 18 4714425; Fax: +46 18 4714059; E-mail: per-ola.carlsson@mcb.uu.se 
a novel directed cellular therapy to improve islet engraftment at the site of implantation in the liver.

\section{MATERIALS AND METHODS}

Animals

All experiments were approved by the Animal Ethical Committee in Uppsala and followed the Principles of Laboratory Animal Care (NIH publication No. 85-23, revised 1985). Adult male C57BL/6 mice were purchased from Taconic (Ry, Denmark), whereas transgenic heterozygous C57BL/6- $\beta$-actin enhanced green fluorescent protein (EGFP) mice, originally obtained from Taconic (Germantown, NY, USA), were bred at Uppsala University.

\section{Islet Isolation and Culture}

Pancreatic islets of C57BL/6 mice were isolated using collagenase digestion (collagenase from Clostridium histolyticum; Roche Diagnostics, Mannheim, Germany) and density gradient purification (14). Islets were thereafter handpicked and cultured free floating in RPMI-1640 (Sigma-Aldrich, St. Louis, MO, USA) supplemented with L-glutamine (2 mmol/l; Sigma-Aldrich), benzylpenicillin (100 U/ml; Roche Diagnostics), and 10\% (v/v) fetal calf serum (Sigma-Aldrich) at $37^{\circ} \mathrm{C}$ in $95 \% \mathrm{O}_{2} / 5 \% \mathrm{CO}_{2}$.

\section{NCSC Preparation, Culture, and Characterization}

Dorsal root ganglia from 11.5-day-old EGFP mice were isolated and used to generate NCSCs from the so-called boundary cap (15). Cells were cultured in N2 medium (Invitrogen, Carlsbad, CA, USA) containing B27 (Life Technologies, Eugene, OR, USA), epidermal growth factor (EGF; $20 \mathrm{ng} / \mathrm{ml}$; R\&D Systems, Minneapolis, MN, USA), and basic fibroblast growth factor (bFGF; $20 \mathrm{ng} / \mathrm{ml}$; R\&D Systems). The medium was changed every other day ( $50 \%$ of the medium replaced with fresh medium) until neurospheres began to form. These were then expanded for 3-5 days free floating in propagation medium (DMEM/ F12 medium; Life Technologies) supplemented with B27, $\mathrm{N} 2$, bFGF (20 ng/ml), and EGF (20 ng/ml) followed by dispersal into single cells by TrypLE Express (1×; Life Technologies). NCSCs prepared in this manner from the boundary cap have previously been shown by us and others to remain in an undifferentiated state being nestin and p75 positive, as well as positive for Brn3A, Ngn1, Ngn2, and Krox20, while few express mature markers of glia or neural cells $(15,21)$. None of the cells express insulin (13).

\section{NCSC Gene Expression}

Total RNA was isolated from approximately $4 \times 10^{5}$ NCSCs using RNeasy plus micro kit (Qiagen, Hilden,

Table 1. Genes Investigated for Expression in Neural Crest Stem Cells (NCSCs)

\begin{tabular}{|c|c|c|}
\hline Gene Symbol & Gene Name & Sequence $\left(5^{\prime}-3^{\prime}\right)$ \\
\hline VEGF-a & Vascular endothelial growth factor-a & $\begin{array}{l}\text { Forward: AAAATCAGTTCGAGGAAAGG } \\
\text { Reverse: TACGTTCGTTTAACTCAAGC }\end{array}$ \\
\hline MMP-2 & Matrix metalloproteinase- 2 & $\begin{array}{l}\text { Forward: ACAGGACATTGTCTTTGATG } \\
\text { Reverse: TACACAGCGTCAATCTTTTC }\end{array}$ \\
\hline MMP-9 & Matrix metalloproteinase- 9 & $\begin{array}{l}\text { Forward: ATCCAGTATCTGTATGGTCG } \\
\text { Reverse: TATAGTGGGACACATAGTGG }\end{array}$ \\
\hline NGF & Nerve growth factor & $\begin{array}{l}\text { Forward: ATAAAGGTTTTGCCAAGGAC } \\
\text { Reverse: GACATTGCTATCTGTGTACG }\end{array}$ \\
\hline $\mathrm{BDNF}$ & Brain-derived neurotrophic factor & $\begin{array}{l}\text { Forward: GTATACTGGGTTAACTTTGGG } \\
\text { Reverse: CATAGTAAGGAAAAGGATGGTC }\end{array}$ \\
\hline GDNF & Glial cell line-derived neurotrophic factor & $\begin{array}{l}\text { Forward: CTTGGAGTTAATGTCCAACTG } \\
\text { Reverse: TAACTTCATCTTAGAGTCCCG }\end{array}$ \\
\hline $\mathrm{Ntf3}$ & Neurotropin 3 & $\begin{array}{l}\text { Forward: GAAGATATTTTGGCAGGAGG } \\
\text { Reverse: ATGAAGAGAAAGGTGGACTC }\end{array}$ \\
\hline Ntf5 & Neurotropin 5 & $\begin{array}{l}\text { Forward: CTCAAATCTCAGTCTGTGTG } \\
\text { Reverse: TCAGGTCTGATAAACAGGAG }\end{array}$ \\
\hline Wnt 1 & Wingless-related MMTV integration site 1 & $\begin{array}{l}\text { Forward: AAGAGTTTCCGAGTTGAAAG } \\
\text { Reverse: AGAGACAAGGAGAATGTAGG }\end{array}$ \\
\hline Cntf & Ciliary neurotrophic factor & $\begin{array}{l}\text { Forward: CTAGTGAAGACAGAAGCAAAC } \\
\text { Reverse: TTCAGGCCTTGATGTTTTAC }\end{array}$ \\
\hline EGF & Epidermal growth factor & $\begin{array}{l}\text { Forward: CAGATCTGTCTTCCTCTCAG } \\
\text { Reverse: CTGAGCAGAACTTTGTAGTC }\end{array}$ \\
\hline FGF-5 & Fibroblast growth factor-5 & $\begin{array}{l}\text { Forward: GAACATAGCAGTTTCCAGTG } \\
\text { Reverse: ACTCCTCGTATTCCTACAATC }\end{array}$ \\
\hline Tbp & TATA box-binding protein & $\begin{array}{l}\text { Forward: GTTCTTAGACTTCAAGATCCAG } \\
\text { Reverse: TTCTGGGTTTGATCATTCTG }\end{array}$ \\
\hline
\end{tabular}


Germany). One microgram total RNA was converted to cDNA with a reverse-transcription system (Promega, Madison, WI, USA) using Oligo (dT) ${ }_{15}$ primers. The Light Cycler System (Roche Diagnostics) and detection with SYBR Green (FastStart DNA Master ${ }^{\text {plus }}$ SYBR Green I; Roche Diagnostics) was used to amplify and analyze generated cDNA. The results are presented as threshold cycle values $\left(C_{t}\right.$ values $)$ in comparison with TATA box-binding protein (TBP) as a "housekeeping gene." Relative mRNA expression was calculated as $2^{-\Delta C_{t}}$. For primers, see Table 1.

\section{NCSC Coating of Islets}

NCSC neurospheres were dissociated (cf. above). Approximately $15 \times 10^{5}$ cells were added to 150 islets in a culture dish. Islets together with NCSCs were incubated

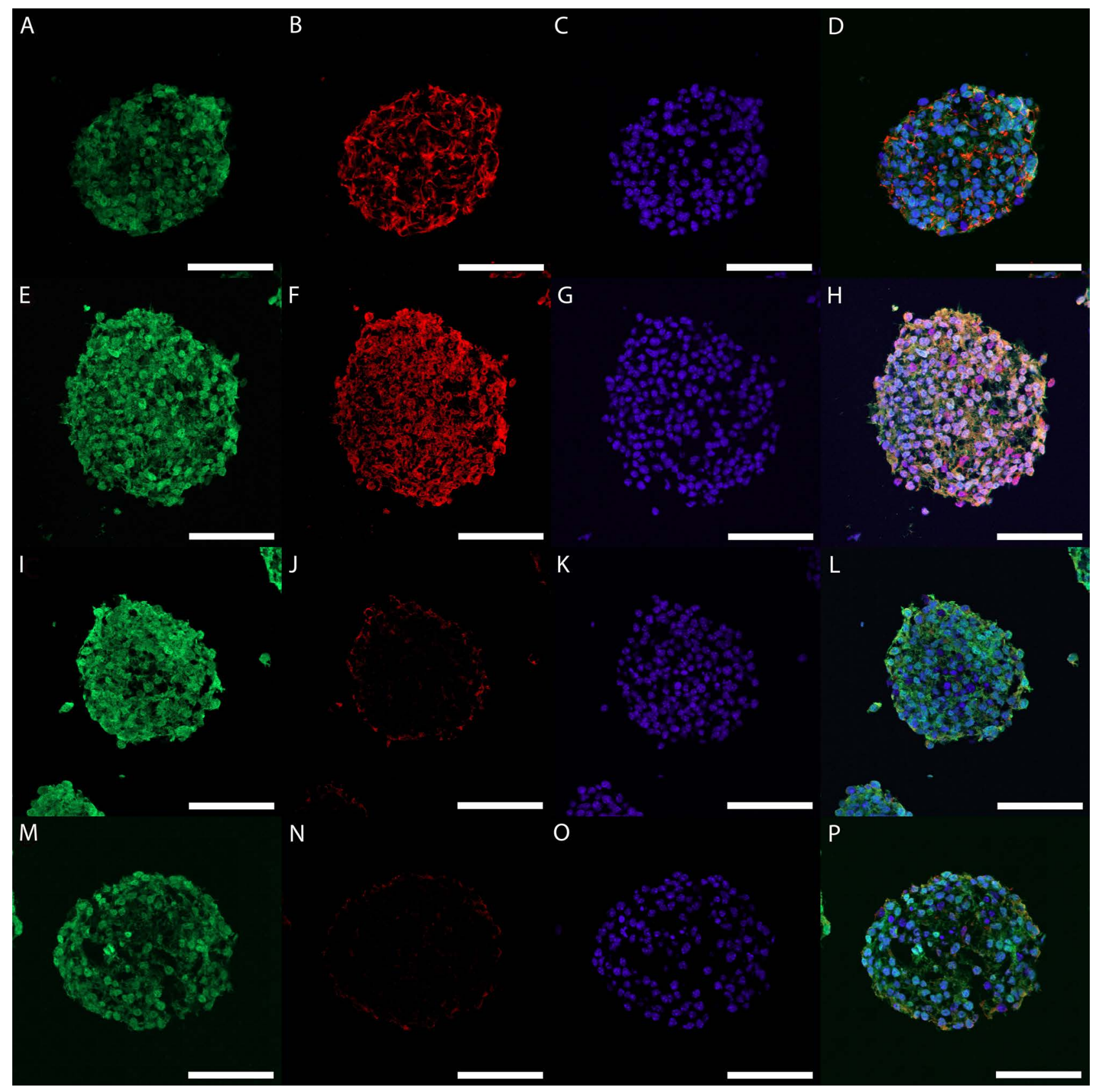

Figure 1. In vitro characteristics of neural crest-derived stem cells (NCSCs). Representative images of propagated enhanced green fluorescent protein (EGFP)-expressing neurospheres (A, E, I, and M in green) stained for nestin (B; red), p75 (F: red), S-100 (J; red), and PGP9.5 (N; red). DAPI staining in neurospheres is shown in blue $(\mathrm{C}, \mathrm{G}, \mathrm{K}$, and $\mathrm{O})$. Overlay images of $(\mathrm{A}-\mathrm{C}),(\mathrm{E}-\mathrm{G}),(\mathrm{I}-\mathrm{K})$, and $(\mathrm{M}-\mathrm{O})$ are shown in $(\mathrm{D}),(\mathrm{H}),(\mathrm{L})$, and $(\mathrm{P})$, respectively. Scale bars: $100 \mu \mathrm{m}$. 
at $37^{\circ} \mathrm{C}$ for $1 \mathrm{~h}$ during gentle shaking and then cultured without shaking overnight.

\section{Islet Transplantation}

C57BL/6 mice were injected intravenously with alloxan (75 mg/kg; Sigma-Aldrich) to render them diabetic (blood glucose concentrations $>16.7 \mathrm{mmol} / \mathrm{L}$ ). Five days later, the mice were transplanted with 300 islets, coated with NCSCs or not coated, selectively into the right liver lobe during anesthesia with avertin $[2.5 \% \mathrm{v} / \mathrm{v}$ solution of $10 \mathrm{~g}$ $97 \% \mathrm{v} / \mathrm{v}$ 2,2,2-tribromoethanol (Sigma-Aldrich) in $10 \mathrm{ml}$ 2-methyl-2-butanol (Kemila, Stockholm, Sweden)] (14). The body weights and blood glucose concentrations of the transplanted animals were monitored. Cure from diabetes was defined as nonfasting blood glucose concentrations $<11.1 \mathrm{mmol} / \mathrm{L}$. One month posttransplantation, an intravenous glucose tolerance test was performed by injection of $2 \mathrm{~g} / \mathrm{kg}$ body weight D-glucose (glucose $300 \mathrm{mg} / \mathrm{ml}$; Fresenius, Uppsala, Sweden) into the tail vein of awake animals. Glucose measurements were made on blood from the cut tip of the tail with glucose reagent strips (Freestyle Lite; Abbott, Alameda, CA, USA) before glucose injection and at 10, 30, 60, and $120 \mathrm{~min}$ later. Glucose disposal rates were calculated for 10-60 min. An additional five animals with 300 islets coated with NCSCs were followed for a prolonged period (140 days). Graft-bearing liver lobes and pancreata were harvested for morphological analysis at 1 month or at 140 days posttransplantation.

\section{Immunohistochemistry}

Tissues were fixed and prepared for immunohistochemistry. Cryosections were incubated for $1 \mathrm{~h}$ with primary antibodies: insulin (guinea pig polyclonal, 1:300; Dako, Glostrup, Denmark), glucagon (mouse monoclonal, 1:1,000; Abcam, Cambridge, UK), CD31 (rat monoclonal, 1:50; BD Bioscience Pharmingen, San Diego, CA, USA), glial fibrillary acidic protein (GFAP; rabbit polyclonal, 1:500; Dako), S100 (rabbit polyclonal, 1:100; Abcam), PGP9.5 (chicken polyclonal, 1:500; Acris Antibody, San Diego, CA, USA), NGF receptor p75 (rabbit polyclonal, 1:200; Millipore, Billerica, MA, USA), and nestin (mouse monoclonal, 1:1,000; BD Bioscience). Secondary antibodies were applied for $1 \mathrm{~h}$ at 1:1,000 dilution. Used antibodies were anti-guinea pig Alexa Fluor 633 (Life Technologies), anti-rat Alexa Fluor 555 (Life Technologies), anti-rabbit Alexa Fluor 555 (Life Technologies), anti-chicken Alexa Fluor 555 (Life Technologies), anti-mouse Alexa Fluor 594 (Life Technologies), and anti-chicken Alexa Fluor 488 (Life Technologies). Sections of paraffin-embedded islet grafts were stained for insulin (guinea pig polyclonal, 1:800; Fitzgerald, Concord, MA, USA) and EGFP (rabbit polyclonal, 1:200; Invitrogen). Secondary antibodies used were horseradish peroxidase-conjugated affinipure donkey antiguinea pig (1:1,000; Jackson Immunoresearch Laboratory,
West Grove, PA, USA) and alkaline phosphatase-conjugated affinipure donkey anti-rabbit (1:500; Jackson Immunoresearch Laboratory). The sections were developed with diaminobenzidine (Sigma-Aldrich) and Vulcan Fast Red (Biocare Medical, Concord, CA, USA) before being counterstained with hematoxylin (Sigma-Aldrich).

\section{Analysis of Nerve and Vascular Density}

The islet graft sections were scanned with a laser scanning microscope Zeiss LSM510-Meta (Zeiss, Oberkochen, Germany). Fluorescence images were subjected to changes in brightness and contrast for optimal visualization. The scanned images were analyzed with Imaris $^{\circledR}$ 7.6.1 (Bitplane Scientific Software; Bitplane AG, Zürich, Switzerland). The vascular density was defined as CD31positive structures per islet area, whereas neural density was defined as area of stained PGP9.5 structures per islet area.

\section{Statistical Analysis}

Values are expressed as means \pm SEM. When only two groups were compared, Student's unpaired $t$-test was used. For multiple comparisons, analysis of variance (ANOVA) and Student-Newman-Keuls method post hoc test were performed. GraphPad Prism 6.0 (GraphPad Software, San Diego, CA, USA) was used for all statistical analyses. For all comparisons, $p<0.05$ was considered statistically significant.

\section{RESULTS}

NCSC Characteristics and Coating

Propagated neurospheres from boundary cap expressed similar characteristic markers as previously described for this cell population $(15,21)$, including expression of

Table 2. Gene Expression Data From Neural Crest Stem Cells

\begin{tabular}{lll}
\hline $\begin{array}{l}\text { Gene } \\
\text { Symbol }\end{array}$ & \multicolumn{1}{c}{ Gene Name } & $\begin{array}{c}\text { Gene Expression } \\
\left(2^{-\Delta \mathrm{C}_{\mathrm{t}}}\right)\end{array}$ \\
\hline VEGF-a & $\begin{array}{c}\text { Vascular endothelial } \\
\text { growth factor-a }\end{array}$ & $9.3 \times 10^{-2} \pm 5.3 \times 10^{-2}$ \\
MMP-2 & Matrix metalloproteinase-2 & $6.3 \times 10^{-3} \pm 0.1 \times 10^{-3}$ \\
MMP-9 & Matrix metalloproteinase-9 & $1.8 \times 10^{-4} \pm 0.2 \times 10^{-4}$ \\
NGF & Nerve growth factor & $2.2 \times 10^{-3} \pm 0.3 \times 10^{-3}$ \\
BDNF & Brain-derived neurotrophic & $3.2 \times 10^{-4} \pm 0.5 \times 10^{-4}$ \\
& factor & \\
GDNF & Glial cell line-derived & $5.4 \times 10^{-5} \pm 3.5 \times 10^{-5}$ \\
& neurotrophic factor & \\
Ntf3 & Neurotropin 3 & $2.9 \times 10^{-2} \pm 1.1 \times 10^{-2}$ \\
Ntf5 & Neurotropin 5 & $1.0 \times 10^{-2} \pm 0.02 \times 10^{-2}$ \\
Wnt 1 & Wingless-related MMTV & $1.5 \times 10^{-3} \pm 0.5 \times 10^{-3}$ \\
& integration site 1 & \\
Cntf & Ciliary neurotrophic factor & $2.3 \times 10^{-1} \pm 1.1 \times 10^{-1}$ \\
EGF & Epidermal growth factor & $2.5 \times 10^{-3} \pm 1.1 \times 10^{-3}$ \\
FGF-5 & Fibroblast growth factor-5 & $4.8 \times 10^{-3} \pm 0.3 \times 10^{-3}$ \\
\hline All
\end{tabular}

All values are given as means \pm SEM from three experiments. Gene expression data were normalized to the housekeeping gene TATA box-binding protein (Tbp). 
nestin and p75, while only some cells and preferentially those peripherally located expressed mature glial (S100ß) and neuronal markers (PGP9.5) (Fig. 1). The NCSCs expressed a vast number of proteins known to potently stimulate angiogenesis and/or neurogenesis, such as vascular endothelial growth factor-a (VEGF-a), matrix metalloproteinase-2 and -9 (MMP-2 and -9), nerve growth factor (NGF), brain-derived neurotrophic factor (BDNF), glial-derived neurotrophic factor (GDNF), neurotrophin 3 and 5 (Ntf3 and Ntf5), Wnt 1, ciliary neurotrohic factor


E

M

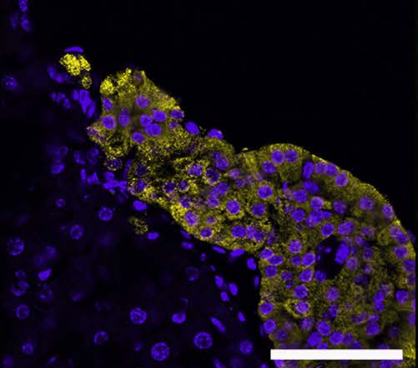

B


\section{C}
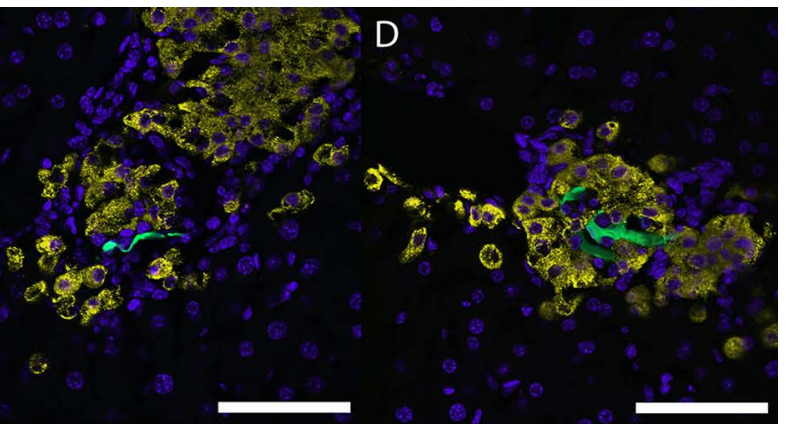

G

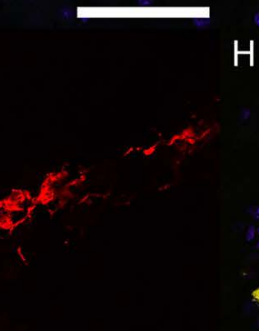

$\mathrm{H}$

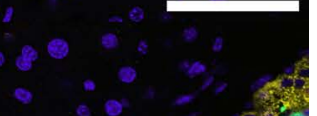

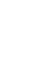


(Cntf), EGF, and fibroblast growth factor-5 (FGF-5) (Table 2). Incubation of islets with dispersed NCSCs during gentle shaking for $1 \mathrm{~h}$ and overnight incubation resulted almost in full coverage of islet surfaces with a thin layer of NCSCs (Fig. 2A, B) and enabled delivery of NCSCs to the site of islet implantation in the liver.

\section{Fate of NCSCs in Islet Grafts}

At 1 month posttransplantation, NCSC-derived cells were easily identified by their EGFP expression. Although cells remained on the islet surface (Fig. 2C), they were not restricted to this location. Some cells had migrated away from the transplants into the liver tissue (data not shown), whereas others were incorporated in the islet tissue (Fig. 2D). The cells had matured and differentiated into both glial cells ( 60\%; GFAP and S100 positive, Fig. $2 \mathrm{G}, \mathrm{K}$ ) and neurons ( 40\%; PGP9.5 positive, Fig. $2 \mathrm{O}$ ). The NCSCs did not seem to differentiate into $\beta$ - or $\alpha$-cells, since stainings for insulin (Fig. 2D) and glucagon (not shown) did not overlap with EGFP-positive cells. At 140 days posttransplantation, NCSC-derived glial and neural cells (EGFP positive) remained to a large extent in the islet periphery or had migrated into the transplanted islets. No morphological changes of NCSC-derived cells, or in the transplanted islet or liver parenchyma, were observed (Fig. 3).

\section{Measurements of Neural Density}

Transplanted control islets showed presence of neural fibers surrounding the implanted islets and also to some extent interspersing the endocrine tissue at 1 month posttransplantation (Fig. 4A, B). Islets coated with NCSCs contained threefold more nerve axons/dendrites, and the



Figure 3. Neural crest-derived stem cell (NCSC)-coated islet in the liver at 140 days posttransplantation. Both the morphology of islet (insulin; brown) and surrounding liver tissue appeared normal. NCSCs (denoted by arrows; red) were still apparent in the islet vicinity. Tissue section was counterstained with hematoxylin. Scale bar: $50 \mu \mathrm{m}$. vast majority of these were not derived from the NCSC coat (Fig. 4C-F).

\section{Measurements of Vascular Density}

One month posttransplantation, a lot of blood vessels were observed in the immediate surroundings of transplanted islets, irrespective of whether or not the islets were coated with NCSCs (Fig. 4G-K). Whereas very few blood vessels could be discerned within transplanted control islets, blood vessel ingrowth into NCSC-coated islets was increased more than threefold (Fig. 4L). Double staining with markers for blood vessels and nerves showed that ingrowth of blood vessels and nerves were in close proximity to each other (Fig. 4M-R).

\section{Islet Graft Function}

All diabetic animals transplanted with 300 control or NCSC-coated islets were cured (Fig. 5A). However, whereas transplanted animals receiving NCSC-coated islets responded similarly as nondiabetic control mice to an intravenous glucose tolerance test at 1 month posttransplantation, transplanted animals receiving naked control islets were glucose intolerant (Fig. 5B). Indeed, by the NCSC coating of islets, glucose disposal rate in the transplanted animals increased almost threefold and was normalized (Fig. 5C). Insulin staining of pancreas of transplanted mice confirmed low densities of $\beta$-cells, excluding the possibility of normalization of blood glucose levels due to $\beta$-cell regeneration.

\section{DISCUSSION}

In the present study, we applied a technique to bioengineer islet surfaces in order to obtain a novel local supply of NCSCs to the site of implantation of intraportally transplanted islets. By NCSC therapy, both an improved revascularization and reinnervation of the islet grafts could be obtained, as well as an improved graft function. NCSCs therefore add to the promising cell therapies previously tested experimentally in islet transplantation $(2,19)$. Application of these different therapies should not be considered mutually exclusive, since, as shown for mesenchymal stem cells and endothelial cells (18), different cells may even have synergistic effects. Moreover, although mesenchymal stem cells have shown excellent performance, NCSCs differ with regard to their immunomodulatory properties $(1,24)$, as well as in their capacities to support engraftment and $\beta$-cell proliferation $(8,16,19,29,31)$.

Pancreatic islets are normally densely innervated with neural crest-derived nerve fibers, which directly regulate both islet hormone secretion and islet blood perfusion $(17,33)$. Nerve signals contribute to $\beta$-cell proliferation (22), and maturing NCSCs induce marked $\beta$-cell proliferation $(13,29)$. Schwann cells, also derived 


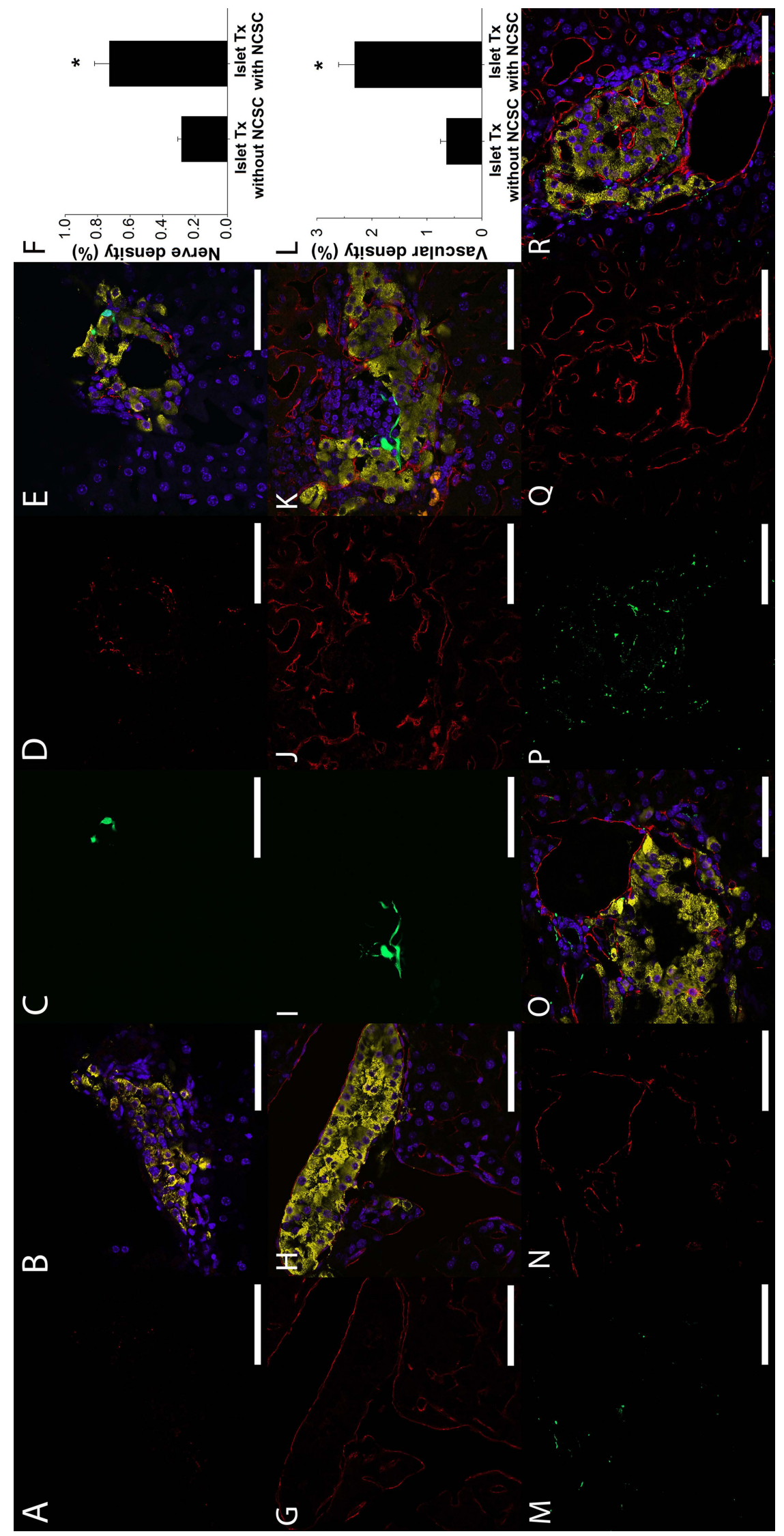

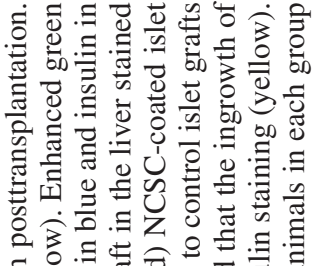



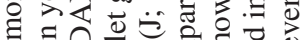
-

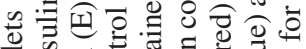

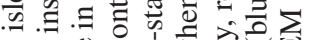
ত্ট ᄋ…

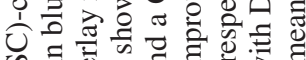

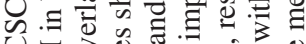



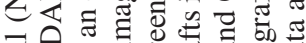

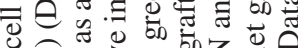


ब.

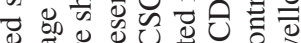
छี क्षे

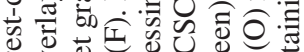
t) 0 के ส․

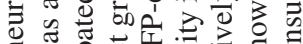



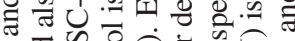

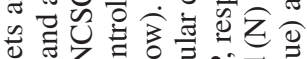



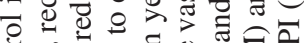

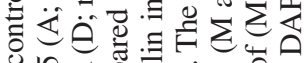
un o

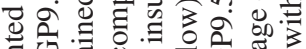

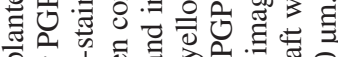
के



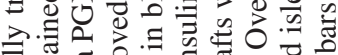

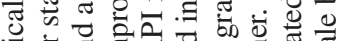


글


$\Xi . \Xi$ क力.

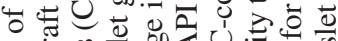

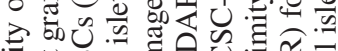

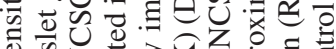


흠

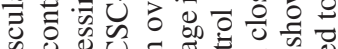
范 च

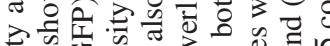
:

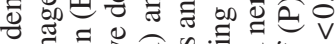

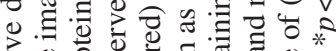





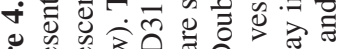
อ อ

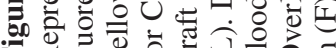





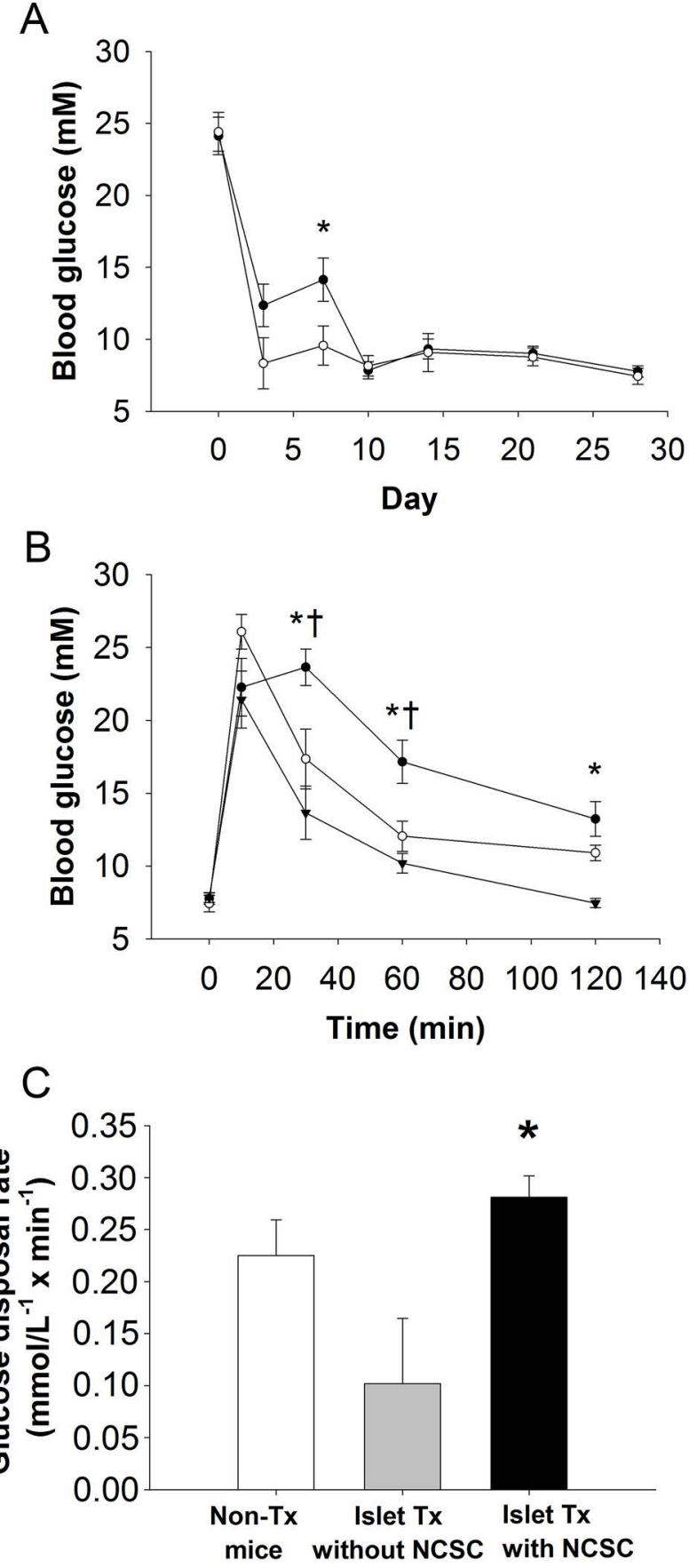

Figure 5. Glucose control in diabetic mice transplanted intraportally with control islets or neural crest-derived stem cell (NCSC)-coated islets. Blood glucose measurements in mice transplanted intraportally with control islets (closed circles) or NCSC-coated islets (open circles) (A). Intravenous glucose tolerance test in nondiabetic, nontransplanted control mice (triangles), in mice transplanted with control islets (closed circles), and in mice transplanted with NCSC-coated islets (open circles) (B). Glucose disposal rate calculated for 10-60 min for the intravenous glucose tolerance test $(\mathrm{C}) .{ }^{*} p<0.05$ compared to control islet graft; $\uparrow p<0.05$ compared to nondiabetic, nontransplanted control mice. Data are means \pm SEM for seven to eight animals in each group. from the neural crest, form a thin layer on the surface of islets and participate in islet repair following injury (36). The transplanted NCSCs matured and differentiated into both glial cells and neurons. However, the increased reinnervation of the islet grafts could not merely be explained by NCSC maturing into neural cells, since most nerve fibers that occurred in the grafts were nonfluorescent, that is, derived from other sources. Investigation of NCSCs showed their capacity to produce many neurotrophic factors, that is, NGF, BDNF, GDNF, Ntf3 and -5, Wnt 1, Cntf, EGF, and FGF-5, to stimulate ingrowth of endogenous nerves from the surrounding liver into the grafts.

The NCSCs also expressed key angiogenic factors, including VEGF-a and matrix metalloproteinases, previously shown to be of critical importance for islet revascularization posttransplantation $(4,9,14,37)$. Moreover, several of the expressed factors known primarily for their neurotrophic effects (NGF, BDNF, GDNF, Ntf3 and -5, Wnt 1) stimulate angiogenesis $(3,11)$. Cell therapy with NCSCs indeed markedly improved revascularization of intraportally transplanted islets. Of particular interest, islets not fragmented upon transplantation, and which we previously observed avascular at 1 month follow-up (14), regularly contained blood vessels when NCSC coated. The present strategy thereby provides a novel means to revascularize also the large number of islets not mechanically damaged at transplantation. New blood vessels were in most cases closely aligned to ingrowing nerves, suggesting similar cues for their growth (7). A recent report also indicated that in pancreatic islets vascular signals are important to coordinate innervation via vascular scaffolding (32). The observed improved islet revascularization thereby adds to the cues for neural ingrowth.

Cotransplantation beneath the renal capsule of neural progenitor cells derived from the brain subventricular zone with pancreatic islets was previously observed to have potent immune modulatory effects, but at the same time generated progenitor cell-derived malignant tumors seen at 140 days of follow-up (24). In the present study, we therefore included experiments to investigate the long-term safety of the present cotransplantation of islets coated with NCSCs into the liver, but did not find any morphological alterations at 140 days posttransplantation. All transplanted animals remained healthy with normal weight gain, and the morphology was similar to that seen 1 month posttransplantation. The NCSCs migrating into the liver tissue were surrounded by apparently normal parenchyma in the graft-bearing livers of both 30- and 140-day-old islet grafts. Islet vascular and neural densities were improved by the presence of NCSCs, and the NCSCs differentiated into both glial and neural cells. No adverse trophic effects (e.g., tumors) could be seen even at the extended follow-up. 
In our study, diabetic animals transplanted with 300 NCSC-coated islets to cure the recipients did not differ in glucose handling from nondiabetic control mice, whereas diabetic animals transplanted with control islets had a significant delay in lowering blood glucose. Indeed, the glucose disposal rate improved almost threefold by the NCSC coating. This improved glucose tolerance by NCSCs likely reflects their previously described trophic effects on $\beta$-cell mass $(13,29)$, their protection from cytokineinduced apoptosis (28), and the presently reported improved engraftment. The simple strategy applied by mere incubation of islets with NCSCs prior to transplantation makes it feasible for implementation in clinical islet transplantation, although NCSCs then probably need to be derived from skin or bone marrow $(27,35)$.

ACKNOWLEDGMENTS: The study was generously supported by the Swedish Research Council projects 20716 (to E.K.) and $55 X-15043$ (to P-O.C), EFSD/JDRF/Novo Nordisk Programme 2012, the Swedish Diabetes Association, the Swedish Juvenile Diabetes Foundation, Diabetes Wellness Sverige, the Swedish Institute Visby Programme, the Novo Nordisk Foundation, Olle Engqvist Byggmästare Fund, AFA insurances, the Signhild Engkvist's Foundation, the Swedish Society of Medicine, and the Magnus Bergvall Foundation. The authors declare no conflicts of interest.

\section{REFERENCES}

1. Abdi, R.; Fiorina, P.; Adra, C. N.; Atkinson, M.; Sayegh, M. H. Immunomodulation by mesenchymal stem cells: A potential therapeutic strategy for type 1 diabetes. Diabetes 57(7):1759-1767; 2008.

2. Berman, D. M.; Willman, M. A.; Han, D.; Kleiner, G.; Kenyon, N. M.; Cabrera, O.; Karl, J. A.; Wiseman, R. W.; O'Connor, D. H.; Bartholomew, A. M.; Kenyon, N.S. Mesenchymal stem cells enhance allogeneic islet engraftment in nonhuman primates. Diabetes 59(10):2558-2568; 2010.

3. Blais, M.; Levesque, P.; Bellenfant, S.; Berthod, F. Nerve growth factor, brain-derived neurotrophic factor, neurotrophin-3 and glial-derived neurotrophic factor enhance angiogenesis in a tissue-engineered in vitro model. Tissue Eng. Part A 19(15-16):1655-1664; 2013.

4. Brissova, M.; Shostak, A.; Shiota, M.; Wiebe, P. O.; Poffenberger, G.; Kantz, J.; Chen, Z.; Carr, C.; Jerome, W. G.; Chen, J.; Baldwin, H.S.; Nicholson, W.; Bader, D.M.; Jetton, T.; Gannon, M; Powers, A.C. Pancreatic islet production of vascular endothelial growth factor-a is essential for islet vascularization, revascularization, and function. Diabetes 55(11):2974-2985; 2006.

5. Cabric, S.; Sanchez, J.; Lundgren, T.; Foss, A.; Felldin, M.; Kallen, R.; Salmela, K.; Tibell, A.; Tufveson, G.; Larsson, R.; Korsgren, O.; Nilsson, B. Islet surface heparinization prevents the instant blood-mediated inflammatory reaction in islet transplantation. Diabetes 56(8):2008-2015; 2007.

6. Calderone, A. Nestin+ cells and healing the infarcted heart. Am. J. Physiol. Heart Circ. Physiol. 302(1):H1-9; 2012.

7. Carmeliet, P.; Tessier-Lavigne, M. Common mechanisms of nerve and blood vessel wiring. Nature 436(7048): 193-200; 2005.

8. Cavallari, G.; Olivi, E.; Bianchi, F.; Neri, F.; Foroni, L.; Valente, S.; La Manna, G.; Nardo, B.; Stefoni, S.; Ventura, C.
Mesenchymal stem cells and islet cotransplantation in diabetic rats: Improved islet graft revascularization and function by human adipose tissue-derived stem cells preconditioned with natural molecules. Cell Transplant. 21(12):2771-2781; 2012.

9. Christoffersson, G.; Henriksnas, J.; Johansson, L.; Rolny, C.; Ahlstrom, H.; Caballero-Corbalan, J.; Segersvard, R.; Permert, J.; Korsgren, O.; Carlsson, P. O.; Phillipson, A.M. Clinical and experimental pancreatic islet transplantation to striated muscle: Establishment of a vascular system similar to that in native islets. Diabetes 59(10):2569-2578; 2010.

10. Froud, T.; Baidal, D. A.; Faradji, R.; Cure, P.; Mineo, D.; Selvaggi, G.; Kenyon, N. S.; Ricordi, C.; Alejandro, R. Islet transplantation with alemtuzumab induction and calcineurin-free maintenance immunosuppression results in improved short- and long-term outcomes. Transplantation 86(12):1695-1701; 2008.

11. Gherghe, C. M.; Duan, J.; Gong, J.; Rojas, M.; KlauberDemore, N.; Majesky, M.; Deb, A. Wnt1 is a proangiogenic molecule, enhances human endothelial progenitor function, and increases blood flow to ischemic limbs in a HGFdependent manner. FASEB J. 25(6):1836-1843; 2011.

12. Gibly, R. F.; Zhang, X.; Lowe, W. L., Jr.; Shea, L. D. Porous scaffolds support extrahepatic human islet transplantation, engraftment, and function in mice. Cell Transplant. 22(5):811-819; 2013.

13. Grouwels, G.; Vasylovska, S.; Olerud, J.; Leuckx, G.; Ngamjariyawat, A.; Yuchi, Y.; Jansson, L.; Van de Casteele, M.; Kozlova, E. N.; Heimberg, H. Differentiating neural crest stem cells induce proliferation of cultured rodent islet beta cells. Diabetologia 55(7):2016-2025; 2012.

14. Henriksnas, J.; Lau, J.; Zang, G.; Berggren, P. O.; Kohler, M.; Carlsson, P. O. Markedly decreased blood perfusion of pancreatic islets transplanted intraportally into the liver: Disruption of islet integrity necessary for islet revascularization. Diabetes 61(3):665-673; 2012.

15. Hjerling-Leffler, J.; Marmigere, F.; Heglind, M.; Cederberg, A.; Koltzenburg, M.; Enerback, S.; Ernfors, P. The boundary cap: A source of neural crest stem cells that generate multiple sensory neuron subtypes. Development 132(11):2623-2632; 2005.

16. Ito, T.; Itakura, S.; Todorov, I.; Rawson, J.; Asari, S.; Shintaku, J.; Nair, I.; Ferreri, K.; Kandeel, F.; Mullen, Y. Mesenchymal stem cell and islet co-transplantation promotes graft revascularization and function. Transplantation 89(12):1438-1445; 2010.

17. Jansson, L.; Hellerstrom, C. Glucose-induced changes in pancreatic islet blood flow mediated by central nervous system. Am. J. Physiol. 251(6 Pt 1):E644-647; 1986.

18. Johansson, U.; Rasmusson, I.; Niclou, S. P.; Forslund, N.; Gustavsson, L.; Nilsson, B.; Korsgren, O.; Magnusson, P. U. Formation of composite endothelial cell-mesenchymal stem cell islets: A novel approach to promote islet revascularization. Diabetes 57(9):2393-2401; 2008.

19. Kang, S.; Park, H. S.; Jo, A.; Hong, S. H.; Lee, H. N.; Lee, Y. Y.; Park, J. S.; Jung, H. S.; Chung, S. S.; Park, K. S. Endothelial progenitor cell cotransplantation enhances islet engraftment by rapid revascularization. Diabetes 61(4):866-876; 2012.

20. Korsgren, O.; Jansson, L.; Andersson, A.; Sundler, F. Reinnervation of transplanted pancreatic islets. A comparison among islets implanted into the kidney, spleen, and liver. Transplantation 56(1):138-143; 1993.

21. Kozlova, E. N.; Jansson, L. Differentiation and migration of neural crest stem cells are stimulated by pancreatic islets. Neuroreport 20(9):833-838; 2009. 
22. Lausier, J.; Diaz, W. C.; Roskens, V.; LaRock, K.; Herzer, K.; Fong, C. G.; Latour, M. G.; Peshavaria, M.; Jetton, T. L. Vagal control of pancreatic ss-cell proliferation. Am. J. Physiol. Endocrinol. Metab. 299(5):E786-793; 2010.

23. Lee, Y.; Ravazzola, M.; Park, B. H.; Bashmakov, Y. K.; Orci, L.; Unger, R. H. Metabolic mechanisms of failure of intraportally transplanted pancreatic beta-cells in rats: Role of lipotoxicity and prevention by leptin. Diabetes 56(9):2295-2301; 2007.

24. Melzi, R.; Antonioli, B.; Mercalli, A.; Battaglia, M.; Valle, A.; Pluchino, S.; Galli, R.; Sordi, V.; Bosi, E.; Martino, G.; Bonifacio, E.; Doglioni, C.; Piemonti, L. Co-graft of allogeneic immune regulatory neural stem cells (NPC) and pancreatic islets mediates tolerance, while inducing NPCderived tumors in mice. PLoS One 5(4):e10357; 2010.

25. Moberg, L.; Johansson, H.; Lukinius, A.; Berne, C.; Foss, A.; Kallen, R.; Ostraat, O.; Salmela, K.; Tibell, A.; Tufveson, G.; Elgue, G.; Nilsson Ekdahl, K.; Korsgren, O.; Nilsson, B. Production of tissue factor by pancreatic islet cells as a trigger of detrimental thrombotic reactions in clinical islet transplantation. Lancet 360(9350):2039-2045; 2002.

26. Monsonego-Ornan, E.; Kosonovsky, J.; Bar, A.; Roth, L.; Fraggi-Rankis, V.; Simsa, S.; Kohl, A.; Sela-Donenfeld, D. Matrix metalloproteinase 9/gelatinase B is required for neural crest cell migration. Dev. Biol. 364(2):162-177; 2012.

27. Nagoshi, N.; Shibata, S.; Kubota, Y.; Nakamura, M.; Nagai, Y.; Satoh, E.; Morikawa, S.; Okada, Y.; Mabuchi, Y.; Katoh, H.; Okada, S.; Fukuda, K.; Suda, T.; Matsuzaki, Y.; Toyama, Y.; Okano, H. Ontogeny and multipotency of neural crest-derived stem cells in mouse bone marrow, dorsal root ganglia, and whisker pad. Cell Stem Cell 2(4):392-403; 2008.

28. Ngamjariyawat, A.; Turpaev, K.; Welsh, N.; Kozlova, E. N. Coculture of insulin-producing RIN5AH cells with neural crest stem cells protects partially against cytokine-induced cell death. Pancreas 41(3):490-492; 2012.

29. Olerud, J.; Kanaykina, N.; Vasylovska, S.; King, D.; Sandberg, M.; Jansson, L.; Kozlova, E. N. Neural crest stem cells increase beta cell proliferation and improve islet function in co-transplanted murine pancreatic islets. Diabetologia 52(12):2594-2601; 2009.

30. Olsson, R.; Olerud, J.; Pettersson, U.; Carlsson, P. O. Increased numbers of low-oxygenated pancreatic islets after intraportal islet transplantation. Diabetes 60(9):2350-2353; 2011.

31. Rackham, C. L.; Chagastelles, P. C.; Nardi, N. B.; HaugeEvans, A. C.; Jones, P. M.; King, A. J. Co-transplantation of mesenchymal stem cells maintains islet organisation and morphology in mice. Diabetologia 54(5):1127-1135; 2011.

32. Reinert, R. B.; Cai, Q.; Hong, J. Y.; Plank, J. L.; Aamodt, K.; Prasad, N.; Aramandla, R.; Dai, C.; Levy, S. E.; Pozzi, A.; Labosky, P. A.; Wright, C. V.; Brissova, M.; Powers, A. C. Vascular endothelial growth factor coordinates islet innervation via vascular scaffolding. Development 141(7):1480-1491; 2014.

33. Rodriguez-Diaz, R.; Abdulreda, M. H.; Formoso, A. L.; Gans, I.; Ricordi, C.; Berggren, P. O.; Caicedo, A. Innervation patterns of autonomic axons in the human endocrine pancreas. Cell Metab. 14(1):45-54; 2011.

34. Ryan, E. A.; Paty, B. W.; Senior, P. A.; Bigam, D.; Alfadhli, E.; Kneteman, N. M.; Lakey, J. R.; Shapiro, A. M. Fiveyear follow-up after clinical islet transplantation. Diabetes 54(7):2060-2069; 2005.

35. Sieber-Blum, M.; Grim, M.; Hu, Y. F.; Szeder, V. Pluripotent neural crest stem cells in the adult hair follicle. Dev. Dyn. 231(2):258-269; 2004.

36. Tang, S. C.; Chiu, Y. C.; Hsu, C. T.; Peng, S. J.; Fu, Y. Y. Plasticity of Schwann cells and pericytes in response to islet injury in mice. Diabetologia 56(11):2424-2434; 2013.

37. Zhang, N.; Richter, A.; Suriawinata, J.; Harbaran, S.; Altomonte, J.; Cong, L.; Zhang, H.; Song, K.; Meseck, M.; Bromberg, J.; Dong, H. Elevated vascular endothelial growth factor production in islets improves islet graft vascularization. Diabetes 53(4):963-970; 2004. 